\title{
Strategi Pencegahan Stunting melalui Rumah Desa Sehat dan Pemanfaatan Lahan Pekarangan Rumah di Desa Karya Indah
}

\author{
Rosma Kadir ${ }^{1}$, Jafar Lantowa ${ }^{2}$ \\ ${ }^{1,2}$ Fakultas Sastra dan Budaya, Universitas Negeri Gorontalo, Jl. Jend. Sudirman No.6, \\ Dulalowo Tim., Kota Tengah, Kota Gorontalo, Gorontalo 96128, Indonesia \\ email: rosmakadirrose@gmail.com ${ }^{1}$, Jafar.lantowa@ung.ac.id ${ }^{3}$
}

\begin{abstract}
Abstrak
Anak sekolah berada pada perkembangan yang cepat dalam proses intelektualnya dan keterampilan serta mulai mempunyai kegiatan fisik yang aktif. Untuk menunjang perkembangan dan fisik yang dilakukan oleh anak sekolah tersebut dibutuhkan berbagai macam zat gizi yang diperlukan dalam jumlah yang mencukupi untuk memenuhi perkembangan dan pertumbuhan yang baik, karena peran gizi sangat menentukan keadaan kesehatan anak. Berkaitan dengan hal tersebut, untuk menciptakan sumber daya manusia yang tentunya banyak faktor yang langsung yang mempengaruhi status gizi meliputi konsumsi makanan dan penyakit infeksi. Faktor tidak langsung meliputi pengetahuan, pendidikan, tingkat pendapatan, pendidikan orang tua, dan besar keluarga. Di negara-negara yang sedang berkembang termasuk Indonesia, masalah gizi menjadi lebih penting dari segi kesehatan masyarakat karena kekurangan gizi dapat menurunkan kerentanan tubuh terhadap beberapa penyakit, khususnya penyakit infeksi.Tujuan dari program pengabdian ini adalah untuk meningkatkan edukasi dan informasi tentang stunting melalui Sosialisasi Pencegahan Stunting serta memupuk kreativitas masyarakat melalui PemanfaatanLahan Pekarangan Rumah. Metode pelaksanaan meliputi Metode sosialisasi, Metode pemanfaatan Poskesdes sebagai Rumah Desa Sehat, metode pembinaan, dan metode pemberdayaan masyarakat. Hasil KKN Tematik adalah Kegiatan sosialisasi, Pembuatan Rumah Desa Sehat, Pembuatan literasi pemanfaatan lahan pekarangan rumah dalam bentuk modul, Pembuatan model taman pemanfaatan lahan pekarangan rumah agar masyarakat yang ingin menggunakan lahan pekarangan rumah sebagai taman bisa meniru model taman yang sudah dibuat oleh mahasiswa KKN Tematik. Saran terkait program KKN ialah Perlu dukungan dari pemerintah setempat dalam pencegahan stunting di desa, khususnya Desa Karya Indah, Perlu kesadaran dari aparat desa, kader kesehatan, dan masyarakat dalam mengelola Poskesdes sebagai Rumah Desa Sehat, Perlu bimbingan dan dukungan dari aparat desa dan karang taruna kepada masyarakat terhadap pemanfaatan lahan pekarangan rumah.
\end{abstract}

Kata Kunci: Strategi Pencegahan Stunting; Rumah Desa Sehat; Lahan Pekarangan Rumah

\begin{abstract}
School children are at a rapid development stage in their intellectual and skill processes and are beginning to have vigorous physical activities. To support the development and physical activity, school children need various kinds of nutrients in sufficient quantities in order to grow and develop properly, because the role of nutrition greatly determines the child's health condition.In this regard, many direct factors are affecting nutritional status, including food consumption and infectious diseases. Moreover, several indirect factors, such as knowledge, education, income level, parental education, and family size, also affected the nutritional status. In developing countries, including Indonesia, nutrition is becoming more critical in terms of public health because malnutrition can reduce immunity to several diseases, especially infectious diseases. This community service program aims to increase education and provide information about stunting through the dissemination of stunting prevention and fostering the creativity of the community through the utilization of the home yard. The implementation methods employed includeddissemination, the use of Poskesdes as a Healthy Village House, coaching, and community empowerment. Thematic Community Service Program outputs are dissemination activities, the formation of Healthy Village Houses and modules on the use of house yards, and the formation of garden models, which are the results of the utilization of house yards that can be emulated by people who want to use their houses as gardens. The advice given regarding this Community Service Program is that the local government needs to support the stunting
\end{abstract}


prevention in the village, especially in Karya Indah Village. Moreover, awareness is needed from village officials, health cadres, and the community in managing Poskesdes as a Healthy Village Home. Guidance and support from village officials and youth organizations are also needed for the community regarding the utilization of home yards.

Keywords: Stunting Prevention Strategies; Healthy Village Homes; Home Yard Utilization

(C) 2019 Rosma Kadir, Jafar Lantowa Under the license CC BY-SA 4.0 Correspondence author: Rosma Kadir, rosmakadirrose@gmail.com, Gorontalo, Indonesia

\section{PENDAHULUAN}

Stunting didefinisikan sebagai indeks tinggi badan menurut usia (TB/U) kurang dari minus dua standar deviasi (-2SD) atau dibawah rata-rata standar yang ada. Stunting pada anak merupakan hasi jangka panjang konsumsi diet berkualitas rendah yang dikombinasikan dengan morbiditas, penyakit infeksi, dan masalah lingkungan (ACC/SCN dalam Jurnal IImu Keperawatan dan Kebidanan, 2020).

Stunting terhadap perkembangan otak sangat merugikan performance anak. Perkembangan otak anak dimasa golden period ( $0-3$ tahun) yang akan menyebabkan sel otak tidak tumbuh sempurna. Hal ini disebabkan karena $80-$ $90 \%$ jumlah sel otak terbentuk semenjak masa dalam kandungan sampai usia 2 tahun. Apabila gangguan tersebut terus berlangsung maka akan terjadi penurunan skor test IQ sebesar $10-13$ poin. Penurunan perkembangan IQ tersebut akan mengakibatkan terjadinya loss generation, artinya anak-anak tersebut akan menjadi beban masyarakat dan pemerintah karena terbukti keluarga dan pemerintah harus mengeluarkan biaya kesehatan yang tinggi akibat warganya mudah sakit (Caulfield, 2010).

Anak sekolah berada pada perkembangan yang cepat dalam proses intelektualnya dan keterampilan serta mulai mempunyai kegiatan fisik yang aktif. Untuk menunjang perkembangan dan fisik yang dilakukan oleh anak sekolah tersebut dibutuhkan berbagai macam zat gizi yang diperlukan dalam jumlah yang mencukupi untuk memenuhi perkembangan dan pertumbuhan yang baik, karena peran gizi sangat menentukan keadaan kesehatan anak. Berkaitan dengan hal tersebut, untuk menciptakan sumber daya manusia yang tentunya banyak faktor yang langsung yang mempengaruhi status gizi meliputi konsumsi makanan dan penyakit infeksi. Faktor tidak langsung meliputi 
pengetahuan, pendidikan, tingkat pendapatan, pendidikan orang tua, dan besar keluarga. Di negara-negara yang sedang berkembang termasuk Indonesia, masalah gizi menjadi lebih penting dari segi kesehatan masyarakat karena kekurangan gizi dapat menurunkan kerentanan tubuh terhadap beberapa penyakit, khususnya penyakit infeksi.

Anak usia sekolah (7 - 12 tahun) memiliki pertumbuhan yang cepat dan aktif. Pada masa ini terjadi proses perkembangan fisiologik dan perkembangan kognitif (Hariyani, 2011). Dalam kondisi tersebut, anak harus mendapat asupan gizi dalam kualitas dan kuantitas yang cukup pada makanan yang dikonsumsinya. Keadaan gizi dan kesehatan pada anak sekolah secara nasional didapatkan prevalensi anak kurus pada usia sekolah 6 - 14 tahun sebesar $13,3 \%$ pada anak laki-laki sedangkan pada anak perempuan sebesar 10,9\%. Prevalensi berat badan berlebih sebesar 9,5\% pada anak laki-laki dan 6,4\% pada anak perempuan (Riset Kesehatan Dasar, 2007). Sementara itu status gizi baik pada anak usia sekolah dan remaja umur 5 - 17 tahun sebesar $75 \%$, gizi kurang 18\%, dan gizi lebih $8 \%$. Status gizi anak dapat mempengaruhi derajat kesehatan anak iu sendiri. Semakin baik status gizinya semakin baik kesehatannya dan lebih jarang sakit. Status gizi tersebut dapat diperoleh dari konsumsi makanan. Kondisi status gizi yang baik dapat tercapai apabila tubuh memperoleh zat-zat gizi dari makanan. Zat-zat gizi tersebut dibutuhkan untuk pertumbuhan fisik, kemampuan kerja sehingga dapat mencapai tingkat kesehatan optimal Stunting merupakan salah satu masalah kesehatan yang menjadi perhatian di Kabupaten Pohuwato. Bupati Pohuwato, Syarif Mbuinga meminta pencegahan stunting atau kegagalan pertumbuhan pada anak di Kabupaten Pohuwato dapat dioptimalkan melalui Gerakan Kolaborasi Mengentaskan dan Mencegah Anak Stunting (Gerbos Emas).

Berdasarkan dari permasalahan tersebut, maka LPPM UNG memberikan kontribusi dalam bentuk pengabdian kepada masyarakat desa dalam program KKN Tematik. Melalui KKN Tematik ini kami mencoba melakukan transfer ilmu dan keahlian kepada masyarakat Kecamatan Buntulia, khusunya di Desa Karya Indah melalui keterlibatan mahasiswa dari beberapa disiplin ilmu. Sebanyak 30 
orang mahasiswa mendampingi masyarakat Desa Karya Indah Kecamatan Buntulia selama 45 hari untuk dapat meningkatkan edukasi dan informasi tentang stunting melalui Sosialisasi Pencegahan Stunting serta memupuk kreativitas masyarakat melalui PemanfaatanLahan Pekarangan Rumah.

\section{METODE PELAKSANAAN}

1. Metode sosialisasi dengan harapan dapat memberikan pemahaman dan kesadaran masyarakat dalam pencegahan stunting.

2. Metode pemanfaatan Poskesdes sebagai Rumah Desa Sehat untuk pusat komunikasi, edukasi, dan informasi tentang kesehatan di Desa Karya Indah, khususnya untuk masalah stunting.

3. Metode pembinaan bagi masyarakat dalam pemanfaatan lahan pekarangan rumah melalui modul yang berisi tentang jenis-jenis tanaman yang bisa ditanaman di Desa Karya Indah serta cara penanamannya.

4. Metode pemberdayaan masyarakat melalui pembuatan taman sebagai contoh pemanfaatan lahan pekarangan rumah di pekarangan rumah Kepala Desa Karya Indah.

Operasional program KKN Tematik terdiri atas 3 tahap yakni tahap persiapan dan pembekalan, tahap pelaksanaan dan rencana keberlanjutan program.

\section{Persiapan}

Mekanisme pelaksanaan kegiatan KKN Tematik meliputi tahapan berikut ini:

1. Koordinasi dengan aparat desa dan serah terima Mahasiswa KKN Tematik dari dosen pembimbing lapangan ke Desa Karya Indah

2. Observasi ke tiap dusun untuk mengetahui keadaan geografis dan demografis Desa Karya Indah

3. Sosialisasi awal ke aparat desa, karang taruna, dan masyarakat dalam rangka memberikan informasi kepada masyarakat tentang program kerja Mahasiswa KKN Tematik di Desa Karya Indah

4. Persiapan pemanfaatan Poskesdes sebagai Rumah Desa Sehat

5. Sosialisasi tentang pencegahan stunting 
6. Peresmian Rumah Desa Sehat sebagai sekretariat bersama dalam pembangunan desa dibidang kesehatan, khususnya pencegahan stunting

7. Pembuatan taman dalam rangka pemanfaatan pekarangan rumah Desa Karya Indah

Hasil yang diharapkan:

1. Adanya kesadaran masyarakat dalam pencegahan stunting

2. Terbentuknya inisiatif masyarakat khususnya kaderisasi kesehatan desa untuk memanfaatkan Rumah Desa Sehat di Poskesdes sebagai sekretariat dibidang kesehatan, khususnya dalam hal pencegahan stunting

3. Terbentuknya kreatifitas masyarakat dalam pemanfaatan lahan pekarangan rumah

\section{Pelaksanaan}

Awal perencanaan pelaksanaan program kerja KKN TEMATIK Tahun 2020 di Desa Karya Indah dilakukan pada hari kedua setelah penyerahan mahasiswa kepada pihak desa. Selanjutnya observasi langsung ke masyarakat desa terkait masalah-masalah yang berhubungan dengan program kerja. Selain itu, mahasiswa bekerja sama dengan aparat desa dan meminta saran mereka terkait pelaksanaan program kerja nanti. Hingga mahasiswa bersama Aparat Desa Karya Indah mengadakan Sosisalisasi Pemaparan Program Kerja Nyata TematikTahun 2020 yang di presentasikan oleh dosen pelaksana dan mahasiswa KKN Tematik Universitas Negeri Gorontalo. Sosialisasi yang dihadiri oleh Kepala Desa, BPD (Badan Pemusyawaratan Desa), BABINSA, tokoh masyarakat, serta warga Desa Karya Indah ini berlangsung dengan baik. Setelah pemaparan program kerja, barulah diskusi terbuka dilakukan antara mahasiswa dan warga yang hadir di sosialisasi guna lebih mengetahui respon masyarakat terhadap rencana pelaksanaan program kerja.

Hasil dari diskusi dan semua saran yang kami terima dari sosialisasi pemaparan program maupun diskusi langsung dengan masyarakat menjadi acuan kami dalam menyusun rencana pelaksanaan program kerja. Menurut 
hasil diskusi, masyarakat tertarik dengan program kerja terkait stunting dan pemanfaatan lahan pekarangan.

Kerjasama antara mahasiswa Kuliah Kerja Nyata TematikTahun 2020 sangatlah penting dalam melaksanakan semua program kerja dengan baik. Untuk itulah kami melakukan pembagian tugas sesuai proksi kerja masingmasing mahasiswa. Uraian tabel dalam bentuk program dan penanggung jawab pelaksanaannya adalah sebagai berikut :

1. Melakukan sosialisasi tentang pencegahan stunting

2. Pemanfaatan Poskesdes sebagai Rumah Desa Sehat

3. Pembuatan modul pemanfaatan lahan pekarangan rumah

4. Pembuatan model pemanfaatan lahan pekarangan rumah

\section{HASIL DAN PEMBAHASAN}

Hasil

Program kerja pencegahan stunting merupakan program utama dari Dosen Pembimbing Lapangan dan mahasiswa KKN Tematik Universitas Negeri Gorontalo Tahun 2020 yang mengangkat salah satu dari 9 pokok masalah yang ada di Kabupaten Pohuwato, yaitu pembentukan dan peningkatan kapasitas Pokja Gerbos Emas Desa. Gerbos Emas atau Gerakan Kolaborasi Mengentaskan dan Mencegah Anak Stunting adalah paket program inovasi Pemerintah Pohuwato dalam rangka intervensi penanganan stunting di Kabupaten Pohuwato. Mekanisme kerja dari program pembentukan dan peningkatan kapasitas Pokja Gerbos Emas dimulai dari kegiatan wawancara dengan kaderisasi kesehatan Desa Karya Indah tentang bayi dan balita stunting di Desa Karya Indah, pengumpulan data kesehatan khususnya data stunting di Puskesmas Buntulia, pemanfaatan Poskesdes sebagai Rumah Desa Sehat, sosialisasi pencegahan stunting yang dibantu oleh Puskesmas Buntulia, peresmian Rumah Desa Sehat, pembuatan modul dan percontohan pemanfaatan lahan pekarangan rumah.

Adapun uraian kerja dari program tematik Gerbos Emas ini adalah sebagai berikut: 


\section{Sosialisasi Stunting dan Peresmian Rumah Desa Sehat}

1. Wawancara dengan Kaderisasi Kesehatan

Program yang kami laksanakan diawali dengan wawancara tentang kondisi bayi dan balita yang ada di Desa Karya Indah dengan kaderisasi kesehatan. Kegiatan ini dilaksanakan pada hari Senin,14 September 2020. Dari hasil wawancara diketahui bahwa terdapat 3 balita stunting dan kasus stunting di Desa Karya Indah baru muncul di tahun ini yang di tahun sebelumnya tidak ada kasus stunting. Adapun observasi tersebut tampak pada gambar berikut.
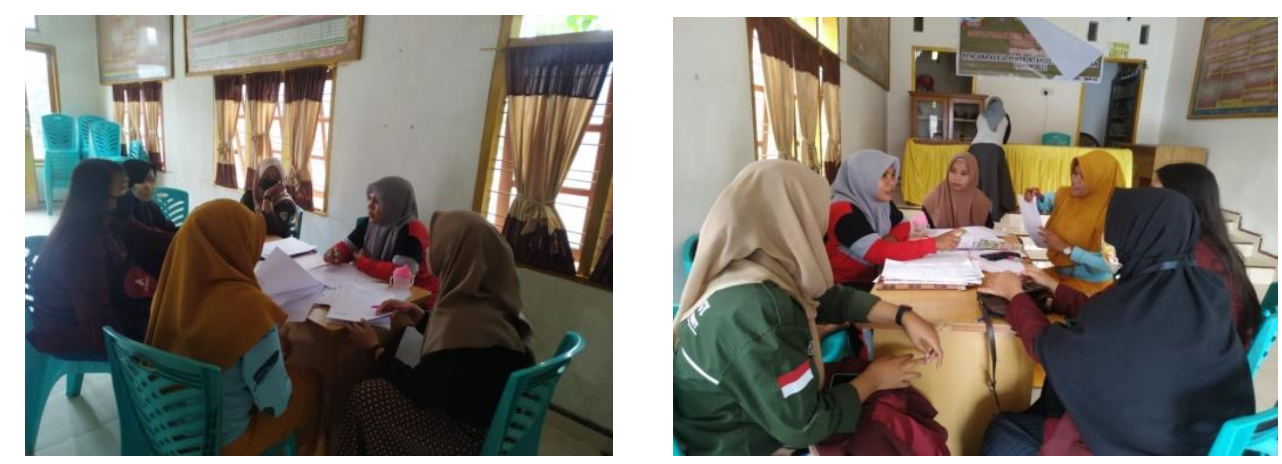

2. Pengumpulan Data Stunting di Puskesmas Buntulia

Pelaksanaan pengumpulan data stunting di Puskesmas Buntulia dilaksanakan satu hari setelah wawancara dengan kaderisasi kesehatan Desa Karya Indah. Kegiatan ini dilaksakan karena kami ingin mendapatkan informasi yang lebih banyak tentang penderita stunting yang ada di Kecamatan Buntulia dan Desa Karya Indah. Data stunting di Kecamatan kami gunakan sebagai pembanding antara jumlah kasus stunting Desa Karya Indah dengan kasus stunting di desa yang terdapat di Kecamatan Buntulia. Selain meminta data, kami juga meminta kesediaan pihak Puskesmas Buntulia untuk membantu kami dalam menyelenggarakan sosialisasi tentang pencegahan stunting sebagai pemateri dalam sosialisasi stunting di Desa Karya Indah. Kegiatan ini tampak pada gambar berikut.

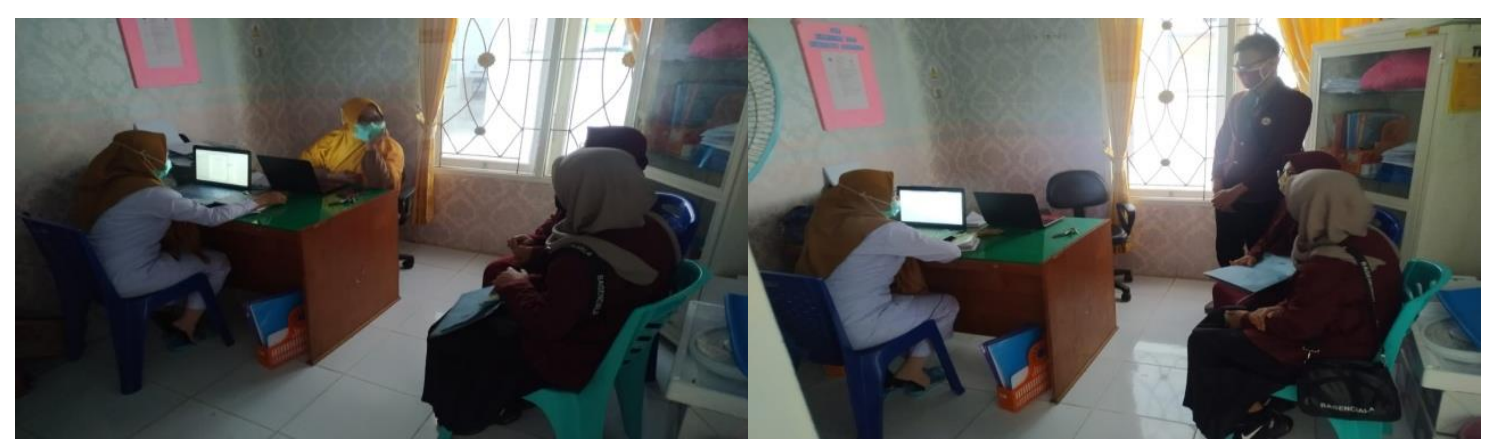




\section{Pemanfaatan Poskesdes sebagai Rumah Desa Sehat}

Kegiatan ini dimulai dari hari Senin - Rabu, 13 - 16 September 2020. Rumah Desa Sehat dibuat di Poskesdes Desa Karya Indah. Pemanfaatan Poskesdes sebagai Rumah Desa Sehat diawali dengan pembersihan lingkungan Poskesdes, baik di luar maupun dalam ruangan, renovasi bagian dalam Poskesdes, pembuatan informasi tentang stunting melalui spanduk dan poster, serta penambahan atribut kesehatan seperti kotak P3K, timbangan, staturemeter, dan tikar stunting.
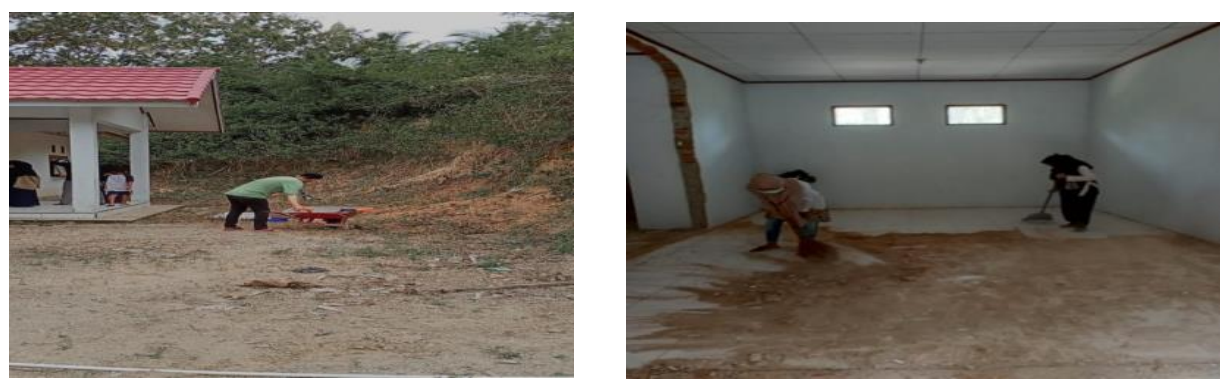

4. Sosialisasi Pencegahan Stunting

Kegiatan sosialisasi pencegahan stunting dilaksanakan di Aula Kantor Desa Karya Indah. Peserta sosialisasi adalah ibu hamil, ibu menyusui, orang tua yang memiliki balita dan kaderisasi kesehatan Desa Karya Indah.

Pembahasan yang diangkat dalam sosialisasi tersebut diantaranya tentang pengertian stunting, bahaya stunting terhadap kesehatan anak, ciri-ciri stunting, dan cara pencegahan stunting. Sosialisasi ini dilaksanakan pada hari Kamis, 17 September 2020.
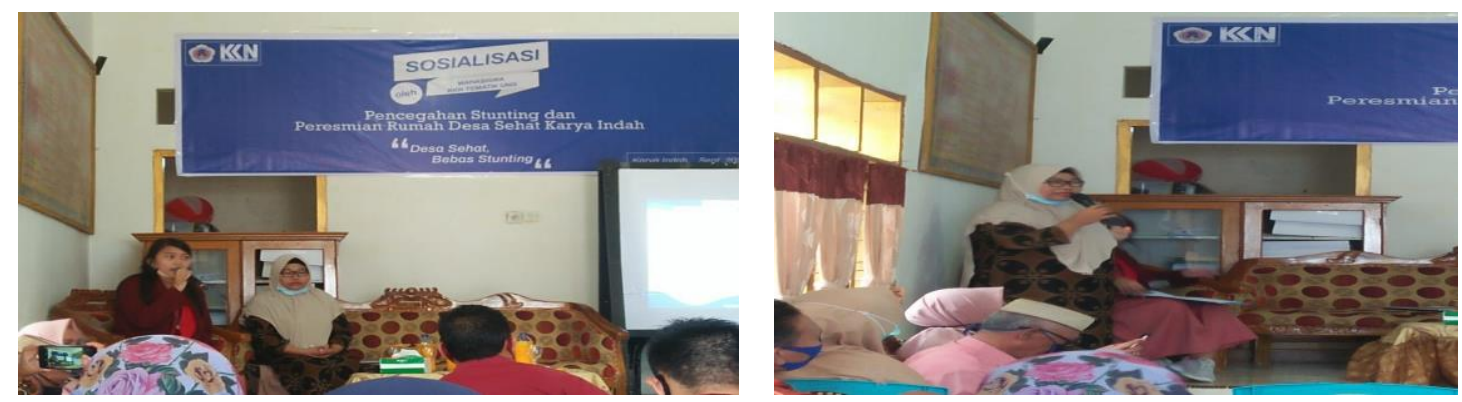


\section{Peresmian Rumah Desa Sehat}

Peresmian Rumah Desa Sehat dilakukan setelah sosialisasi pencegahan stunting selesai. Rumah Desa Sehat diresmikan melalui pemotongan pita oleh Dosen Pembimbing Lapangan, Kepala Desa, serta Sekretaris Kecamatan Buntulia yang disaksikan oleh mahasiswa KKN Tematik, beberapa petugas Puskesmas Buntulia, dan masyarakat Desa Karya Indah.
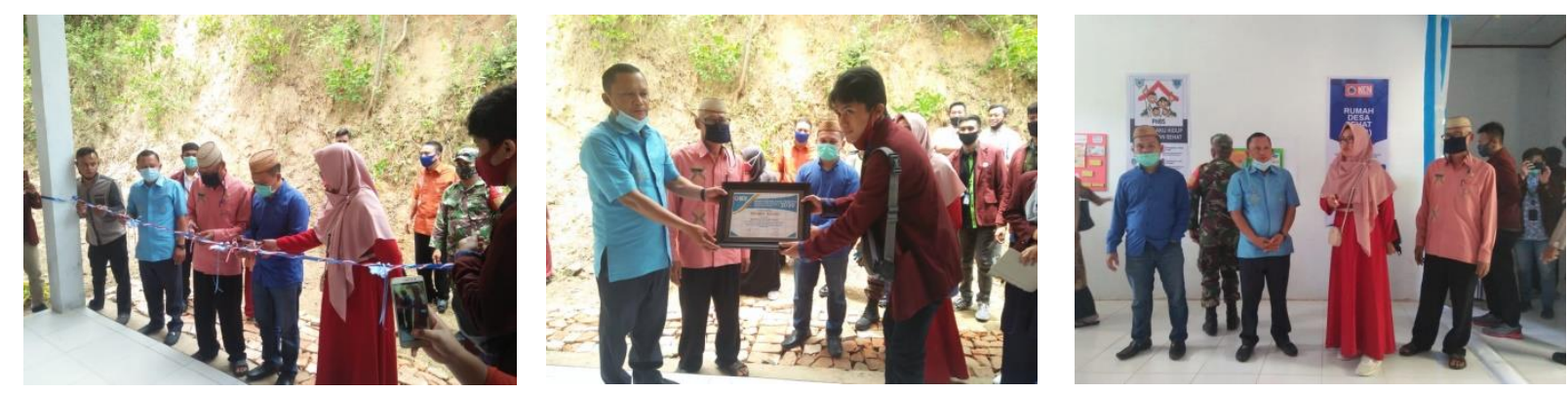

6. Pembuatan Modul dan Model Pemanfaatan Lahan Pekarangan Rumah

Pelaksanaan kegiatan pembuatan modul dan model lahan pekarangan rumah dilaksanakan selama satu minggu, terhitung dari tanggal 26 September - 3 Oktober 2020. Tanaman yang dapat kami tanam pada lahan pekarangan rumah ada 7 tanaman yang terdiri dari tanaman hias, tanaman obat-obatan, dan sayur mayur.

\section{Pemb:}
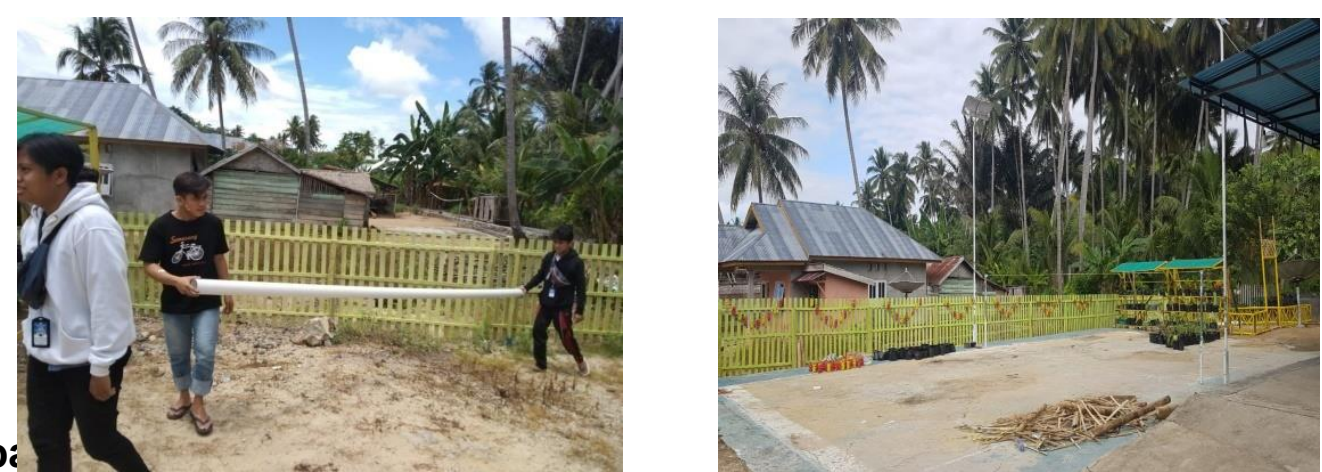

Pada hari pertama setelah sampai di Desa Karya Indah, kami melakukan observasi ke setiap dusun untuk mencari informasi tentang apa saja permasalahan yang ada di Desa Karya Indah, yang masalahnya terdapat pada salah satu dari 9 pokok masalah Kabupaten Pohuwato. Setelah melakukan observasi, pada malam harinya kami melakukan pertemuan dengan aparat 
desa, tokoh masyarakat, serta masyarakat dengan tujuan untuk menjelaskan 9 pokok masalah. Kami juga melakukan diskusi dengan masyarakat terkait masalah apa yang akan kami lakukan pada program kerja selama KKN berlangsung. Setelah melakukan diskusi, akhirnya kami beserta masyarakat sepakat untuk mengangkat masalah tentang kesehatan khususnya pada masalah stunting. Untuk itu kami memilih program kerja tentang pembentukan dan peningkatan kapasitas Pokja Gerbos Emas Desa.

Pada kegiatan pertama, kami melakukan wawancara kepada kaderisasi kesehatan yang ada di Desa Karya Indah. Kegiatan ini bertujuan untuk mengetahui bagaimana kondisi kesehatan anak serta masalah stunting di Desa Karya Indah. Kader Kesehatan mengatakan bahwa ada 3 kasus stunting di Desa Karya Indah yang penderitanya adalah balita. Dari hasil wawancara, ditemukan bahwa munculnya kasus stunting di Desa Karya Indah disebabkan oleh kurangnya informasi dan edukasi tentang bahaya serta bagaimana cara pencegahan stunting. Hal ini disebabkan oleh tempat pelayanan kesehatan yang kurang memadai. Desa Karya Indah memiliki Poskesdes yang masih layak pakai tetapi sudah tidak dipergunakan lagi.Kader kesehatan mengatakan bahwa Poskesdes tidak dipergunakan selama 5 tahun. Selain itu, munculnya kasus stunting disebabkan karena masyarakat Desa Karya Indah yang acuh terhadap bahaya stunting. Untuk itu kami berinisiatif membuat sosialisasi tentang pencegahan stunting untuk menambah wawasan masyarakat tentang bahaya serta pencegahan stunting. Sebelum melakukan sosialisasi, kami mengunjungi Puskesmas Buntulia untuk meminta data kesehatan, khususnya data stunting yang ada di Kecamatan Buntulia. Data tersebut kami gunakan untuk membandingkan jumlah kasus stunting yang ada di Desa Karya Indah dengan desa-desa yang ada di Kecamatan Buntulia. Menurut data yang kami dapat, jumlah kasus stunting di Desa Karya Indah lebih banyak dibandingkan dengan desa-desa di Kecamatan Buntulia.

Berdasarkan hasil wawancara dengan kader kesehatan dan data yang didapat dari puskesmas, kami berinisiatif untuk membuat Rumah Desa Sehat (RDS) yang berlokasi di Poskesdes. Rumah Desa Sehat dibuat dengan tujuan 
untuk membantu pemerintah desa dalam pengelolaan sumber daya manusia yang utamanya di bidang kesehatan. RDS mempunyai fungsi sebagai pusat informasi pelayanan sosial dasar di desa, khususnya bidang kesehatan serta sebagai ruang literasi kesehatan di desa. Sebelum pembuatan Rumah Desa Sehat, kami melakukan observasi ke Poskesdes untuk melihat bagaimana situasi dan kondisi disana. Berdasarkan hasil observasi, Poskesdes tidak digunakan lagi selama 5 tahun karena lokasinya yang tidak strategis. Lokasi Poskesdes berada di belakang kantor desa yang terhalang oleh tebing yang cukup tinggi sehingga Poskesdes tidak terlihat sama sekali dari jalan utama. Meskipun kondisi Poskesdes masih layak pakai tetapi karena lokasinya yang tidak strategis membuat kader kesehatan tidak memiliki inisiatif untuk mengurus Poskesdes. Melihat lokasi Poskesdes yang tidak strategis, kami berencana membuat Rumah Desa Sehat bukan di Poskesdes namun ada beberapa masyarakat yang menginginkan Poskesdes kembali beroperasi supaya ketika masyarakat membutuhkan pertolongan dari tenaga kesehatan bisa terlebih dahulu datang ke Poskesdes. Masyarakat mengeluh untuk datang ke puskesmas karena lokasinya yang agak jauh. Untuk itu kami sepakat memanfaatkan Poskesdes sebagai Rumah Desa Sehat. Kegiatan ini dimulai dari pembersihan di dalam dan di luar ruangan, renovasi bangunan dengan memperluas ruang Poskesdes, mengisi Poskesdes dengan papan informasi tentang kesehatan yang khususnya tentang stunting. Hambatan yang kami alami selama pelaksanaan program Rumah Desa Sehat adalah biaya yang sangat minim untuk membeli peralatan kesehatan lainnya yang harusnya terdapat pada Poskesdes dan cuaca yang kurang mendukung.

Selanjutnya adalah kegiatan sosialisasi tentang pencegahan stunting yang dirangkaikan dengan peresmian Rumah Desa Sehat. Pada kegiatan sosialisasi, kami dibantu oleh petugas Puskesmas Buntulia dalam membawakan materi tentang stunting. Selama berjalannya kegiatan, masih banyak ibu-ibu yang belum bahkan tidak paham tentang stunting. Walaupun dalam sosialisasi para peserta kurang aktif bertanya, tetapi kegiatan tersebut berjalan dengan baik. Selesai dari kegiatan sosialisasi, kami beserta aparat desa, petugas 
puskesmas, dan masyarakat desa melaksanakan peresmian Rumah Desa Sehat. Respon masyarakat tentang pembuatan Rumah Desa Sehat sangat baik sehingga membuat kami merasa senang karena program kerja dalam rangka pembuatan dan peningkatan Pokja Gerbos Emas sesuai dengan harapan kami.

Selama melakukan observasi ke setiap rumah warga di 4 dusun, kami melihat banyak pekarangan rumah warga yang luas namun tidak dimanfaatkan dengan baik. Banyak pekarangan rumah yang dibiarkan begitu saja, ada juga yang hanya dijadikan lahan parkir kendaraan. Melihat kondisi tersebut, kami membuat kegiatan tambahan yaitu pembuatan modul dan model lahan pekarangan rumah. Pemanfaatan lahan pekarangan rumah kami buat dalam rangka pencegahan stunting karena tanaman-tanaman yang ditanam di pekarangan adalah tanaman yang bisa mencegah stunting pada anak. Model taman dibuat di pekarangan rumah Kepala Desa Karya Indah sebagai contoh agar masyarakat bisa meniru model dari taman yang bisa dibuat di pekarangan rumah masing-masing. Selain model taman, kami juga membuat literasi tentang pemanfaatan lahan pekarangan rumah melalui modul. Modul yang dibuat berisi tentang jenis-jenis tanaman, manfaat tanaman bagi kesehatan, dan cara penanaman tanaman. Tanaman yang ada pada modul antara lain tanaman sayur diantaranya bayam, sawi, kacang panjang. Tanaman rempah-rempah yaitu kemangi dan jahe. Tanaman obat-obatan diantaranya mayana, serai, dan kumis kucing. Tanaman hias antara lain bunga pukul 9 pagi, kamboja, dan asoka. Modul kami serahkan kepada tiap kepala dusun dan mereka yang akan menjelaskan kepada masyarakat. Dari berbagai jenis tanaman yang ada pada modul, kami hanya menanam beberapa tanaman di contoh lahan pekarangan yang kami buat. Tanaman yang ditanam diantaranya bunga pukul 9, kamboja, tanaman cabai, kemangi, daun bawang, kumis kucing, dan kangkung. Untuk media tanamnya, kami menggunakan media tanah. Ada tanaman yang kami tanam langsung di tanah, ada yang kami tanam di dalam polybag, dan juga ada yang ditanam di pipa. Hambatan yang kami dapat selama pembuatan modul dan model lahan pekarangan adalah lokasi pengambilan tanah yang jauh sehingga membutuhkan waktu yang lama untuk menyelesaikan pembuatan 
contoh pemanfaatan lahan pekarangan rumah. Selain itu, cuaca yang kurang mendukung juga turut serta menghambat pekerjaan.

\section{KESIMPULAN}

Program kerja mahasiswa KKN Tematik Universitas Negeri Gorontalo Tahun 2020 di Desa Karya Indah Kecamatan Buntulia Kabupaten Pohuwato mengambil 1 dari 9 pokok masalah utama yang ada di Kabupaten Pohuwato, yaitu Pembentukan dan Peningkatan Kapasitas Pokja Gerbos Emas Desa. Gerbos Emas atau Gerakan Kolaborasi Mengentaskan dan Mencegah Anak Stunting yang dilakukan oleh mahasiswa KKN Tematik adalah sebagai berikut :

1. Kegiatan sosialisasi tentang pencegahan stunting bertujuan untuk memberikan informasi dan edukasi kepada masyarakat, khususnya ibu hamil, ibu menyusui, dan orang tua yang memiliki balita tentang bahaya stunting dan cara pencegahannya.

2. Pembuatan Rumah Desa Sehat yang berlokasi di Poskesdes Desa Karya Indah sebagai sekretariat bersama dalam pembangunan desa dibidang kesehatan serta menjadi pusat komunikasi, edukasi, dan informasi pelayanan kesehatan, khususnya untuk stunting.

3. Pembuatan literasi pemanfaatan lahan pekarangan rumah dalam bentuk modul yang bertujuan untuk menambah informasi dan wawasan masyarakat tentang tanaman yang bisa ditanam di pekarangan rumah serta media tanam dan cara penanaman tanamannya.

4. Pembuatan model taman pemanfaatan lahan pekarangan rumah agar masyarakat yang ingin menggunakan lahan pekarangan rumah sebagai taman bisa meniru model taman yang sudah dibuat oleh mahasiswa KKN Tematik

Adapun saran terkait dengan hasil KKN Tematik adalah sebagai berikut.

1. Perlu dukungan dari pemerintah setempat dalam pencegahan stunting di desa, khususnya Desa Karya Indah

2. Perlu kesadaran dari aparat desa, kader kesehatan, dan masyarakat dalam mengelola Poskesdes sebagai Rumah Desa Sehat 
3. Perlu bimbingan dan dukungan dari aparat desa dan karang taruna kepada masyarakat terhadap pemanfaatan lahan pekarangan rumah

\section{UCAPAN TERIMA KASIH}

Sehubungan dengan terlaksananya semua rangkaian program KKN Tematik, maka kami mengucapkan terima kasih kepada seluruh pihak terkait.

\section{REFERENSI}

Caulfield, LE. 2010. Stunting, Wasting and Micronutrient Deficiency Disorders. New York: The World Bank and Universit Pess

Hariyani, S. 2011. Gizi Untuk Kesehatan Ibu dan Anak. Yogyakarta: Graha IImu Izah, N dkk. 2020. Analisis dan Sebaran Determinan Stunting Pada Balita Berdasarkan Pola Asuh (Status Imunisasi dan Pemberian ASI Eksklusif). [Jurnal: Ilmu Keperawatan dan Kebidanan]. Tegal: Politeknik Harapan Bersama

Riset Kesehatan Dasar. 2007. Badan Litbangkes, Departemen Kesehatan Republik Indonesia, Jakarta 